\title{
Chapter 14 \\ Economic Class and Labour Market \\ Segregation: Poor and Middle-Class \\ Workers in Developing Asia and the Pacific
}

\author{
Phu Huynh and Steven Kapsos
}

\begin{abstract}
Using an absolute definition of poverty and economic classes, this paper presents trends and estimates of the poor, near-poor and middle-class working population in developing Asia and the Pacific. It finds that since 1991, working poverty has fallen remarkably, while middle-class jobs now account for nearly two-fifths of all employment in the region (671 million middle-class workers). However, a sizeable share of workers (around $28 \%$ or 497 million) still lives just above the poverty line and remains highly vulnerable to falling into poverty. This paper also applies a class-based framework for assessing inequality in the labour market, with a special focus on Cambodia, India, Indonesia and Viet Nam. It provides empirical evidence that economic participation is inversely related to affluence, while educational attainment and access to better quality jobs both increase with higher economic class status. In addition, it presents sex- and age-disaggregated analysis to highlight particular gaps for poor women and youth, and the measures that can help strengthen their position in the labour market.
\end{abstract}

Keywords Working poverty $\cdot$ Middle class $\cdot$ Labour markets

\subsection{Introduction and Background}

Since the onset of the global financial crisis in 2008, economic prospects around the world have been tenuous and have spurred policy-makers in developing Asia to re-examine the current model of economic growth. With the slow recovery in

\author{
P. Huynh $(\bowtie)$ \\ Regional Office for Asia and the Pacific, International Labour Organization, \\ Bangkok, Thailand \\ e-mail: huynh@ilo.org \\ S. Kapsos \\ International Labour Organization, Geneva, Switzerland \\ e-mail: kapsos@ilo.org
}


external markets, policy focus in many countries of the region has shifted towards fostering domestic consumption and investment, and increasing intra-regional exports.

Domestic markets and intra-regional trade in Asia could be bolstered significantly by a growing and thriving middle class. Evidence suggests that being middle class is associated with better access to jobs, with regular wages and greater investment in health and education (Banerjee and Duflo 2008). In recent decades, the expansion of the middle class in developing Asia has been remarkable, rising from $21 \%$ of the total population in 1990 to $56 \%$ in 2008 (Chun 2010). ${ }^{1}$

While existing research studies have provided estimates of the size of the middle class and others have examined trends in working poverty, less is known about the specific job-related features of different economic classes. ${ }^{2}$ To that end, this paper presents new measurements of workers by economic class in developing Asia and the Pacific and their distinguishing employment characteristics. It aims to shed light on some decent work challenges that must be addressed in order to eradicate working poverty and foster growth of middle-class jobs.

\subsection{Data and Methodology}

A critical starting point in defining economic classes is whether the measurement should be relative or absolute. Defining economic classes in relative terms, for instance, by setting the threshold for the middle class between 75 and $125 \%$ of the median national income or consumption level is useful for assessing social exclusion, particularly in middle- and upper-income economies, where the vast majority of the population is living above the subsistence level. However, relative measures of economic class have distinct disadvantages, particularly in the context of this paper. First, relative class definitions would result in varying class thresholds across countries and hinder cross-country comparisons and the production of regional and global estimates. Second, relative measures may not be appropriate for the least developed economies, in which significant portions of the population may be living below or near poverty levels (Kapsos and Bourmpoula 2013).

Thus, this paper follows the economic class definitions using absolute terms set forth in Kapsos and Bourmpoula (2013), classifying workers living in households with per capita consumption or income below US\$1.25 per day (at purchasing power parity) as "extreme working poor" (class 1), those living in households with per capita consumption or income between US\$1.25 and US\$2 per day as "moderate working poor" (class 2), and between US\$2 and US\$4 as "near-poor workers" (class 3). Given the relatively small cohort of workers above US\$13 per day in

\footnotetext{
${ }^{1}$ Estimates are based on an absolute definition of consumption expenditures equalling US\$2US\$20 per person per day (in 2005 purchasing power parity US dollars).

${ }^{2}$ For further discussion on working poverty, see, for example, Kapsos (2004).
} 
our sample of countries, we have opted to combine the two middle-class cohorts defined by Kapsos and Bourmpoula (2013), corresponding to US\$4-US\$13 and US\$13 and above, into one group covering the "developing middle class and above" (class 4).

Class 1 follows the definition of extreme poverty utilized for the Millennium Development Goals (MDGs) as set forth by Chen and Ravallion (2008). Class 2 is consistent with the widely used international measurement of moderate poverty. The US\$2 per day upper threshold for this class is equivalent to the median poverty line among a sample of national poverty lines for developing and transition economies. This measure is intended to provide an indication of those households whose members are poor, but do not fail to meet basic human needs such as an acceptable daily caloric intake.

Class 3 is established as a measure of workers who are not poor, but are highly vulnerable to slipping into poverty. The choice of US\$4 as an upper bound for this group follows the findings of Banerjee and Duflo (2008) and Kapsos and Bourmpoula (2013) related to key demographic, health, education and labour market characteristics for this group. Across a sample of 39 developing countries, Kapsos and Bourmpoula (2013) find that a substantially higher share of the nearpoor class of workers is in wage employment $(35.3 \%)$ than the two working poor classes. However, they find that the near-poor segment clearly differs from the middle-class segments, which have more than $60 \%$ of workers in wage employment. Thus, workers in the "near-poor" class are much more likely than their middle-class counterparts to be in informal, vulnerable jobs.

Class 4 encompasses the "developing middle class and above" or those workers living in households with per capita consumption of US\$4 and above. As a point of reference, Ravallion (2008) notes that the US poverty line in 2005 is equal to approximately US\$13 per person per day. Many of the workers in this class are, therefore, poor based on a developed world absolute standard, but living above the threshold of poverty or near poverty of the lower three classes. Most workers in this class are a nascent consumer class and are able to afford non-essential goods and services, including some international consumer goods. They are more likely to have higher levels of education and to have access to quality health care than the lower classes. Workers at the upper end of this class are likely to be able to afford a wide range of international consumer products and would be considered middle class based on a developed world standard.

It should be noted that there is little consensus in the literature as to an appropriate absolute definition of the middle class in developing countries. The definitions utilized in this paper are similar to Ravallion (2009), who defines the middle class in developing countries as those living in households with per capita consumption between US\$2 and US\$13 per day at PPP. In a comparable vein, Banerjee and Duflo (2008) define the middle class as those living between US\$2 and US\$10 per day. Focusing on developing countries in Asia, Chun (2010) defines the middle class as those with per capita consumption between US\$2 and US\$20 and notes that a large share of people in the US\$2-US\$4 range have high degrees of vulnerability to poverty, while those in the range of US\$4 to US\$10 per 
day are able to live beyond the subsistence level, consuming non-essential goods and having the ability to save.

Definitions of the middle class that differ substantially from that used in the present analysis include Ferreira et al. (2013), who define middle-class households in Latin American countries as those with between US\$10 and US\$50 in per capita income. The lower bound is based on a $10 \%$ probability of falling into poverty over a 5-year period. The authors argue that this definition is primarily applicable for middle-income countries. Kharas (2010) defines the middle class as individuals living in households with per capita daily consumption between US\$10 and US $\$ 100$ at PPP. The lower bound is set at the average poverty line of Portugal and Italy, while the upper bound is equal to twice the median income in Luxembourg. The Kharas definition sets a high bar for "middle class", consistent with a focus on a "consumer class", akin to consumers in the developed world. Similarly, Loayza et al. (2012) define the middle class as those households with per capita incomes above US $\$ 10$ at PPP.

Following past practice for defining the working poor, the estimates of employment by economic class presented here are based on a cross-tabulation of employment status and economic class status, whereby employment status is defined at the individual level (whether or not an individual is employed), while economic class status is determined by per capita household consumption in the household in which the individual lives. The estimate of total employment in a given class is equal to the number of persons of working age that (1) are employed and (2) are living in a household with per capita consumption between the upper and lower limits of per capita consumption for the economic class. The regional and sub-regional estimates and projections in Sect. 14.3 are based on an econometric model that utilizes a database covering 62 household surveys worldwide, of which 12 countries are from the developing Asia-Pacific region (Kapsos and Bourmpoula 2013).

In Sect. 14.4, a sample of four developing Asian countries was selected in order to highlight detailed labour market characteristics of the various economic classes. The selected countries are Cambodia, India, Indonesia and Viet Nam, and these were chosen with the aim of having broad regional coverage, diversity in population size and national per capita income levels, and the requirement of available, nationally representative surveys that allow for cross-tabulations of household consumption variables with employment indicators. The primary data sources used for each country were the Cambodia Socio-Economic Survey 2004, Indonesia Socio-Economic Survey (SUSENAS) 2002, India National Sample Survey of Employment and Unemployment 2009-2010, and Viet Nam Household Living Standard Survey $2006 .{ }^{3}$ It is important to acknowledge that the analysis in Sect. 14.4 is primarily descriptive and does not examine longitudinal trends or assess causality. In other words, it does not attempt to determine, for example,

\footnotetext{
${ }^{3}$ Given variances in survey years and design, strict cross-country comparisons were not always feasible.
} 
whether higher economic class leads to better access to wage employment or conversely whether holding a salaried job leads to more affluent class status. These other approaches to understanding class-based inequalities in the labour market are critical, but beyond the scope of that section.

\subsection{Employment and Economic Class in Asia and the Pacific: Regional Trends and Projections}

\subsubsection{Estimates, 1991-2012}

Over the past two decades, the Asia-Pacific region has undergone a dramatic shift in the distribution of workers across economic classes (see Fig. 14.1). In 1991, around $55 \%$ of the region's workers were living in extreme poverty, with a further $25 \%$ living in moderate poverty and nearly $14 \%$ in the near-poor category. Eighty per cent of the region's workforce was poor and only $5 \%$ of the workforce was living with their families on more than US $\$ 4$ per person per day in the middle class and above category.

By 2012, the share of the extreme working poor decreased to around $13 \%$, while the share of the moderate working poor declined to just over $20 \%$, for a total of $34 \%$ of the workforce living in poverty-a remarkable decline of 46 percentage points over two decades. The share of the near poor over this period rose to around $28 \%$ of the workforce. This increase in workers above but near the poverty line is not surprising, as many workers have escaped poverty, but have not increased their productivity to such an extent as to join the middle class. Yet, many workers are clearly productive enough for a middle-class standard of living - nearly $38 \%$ of the region's workforce was middle class in 2012, an increase of 33 percentage points since 1991. Moreover, in every year since 1998, the largest growth in absolute employment in Asia and the Pacific has been middleclass employment. Most new jobs in the region are middle-class jobs, which is a remarkable development given the extremely small base from which the region's middle class has grown. Viewed in this light, Asia's development over the past two decades has been a tremendous success.

Analysis of sub-regional data indicates that this rapid development in Asia and the Pacific as a whole has been driven largely by the extraordinary growth in middle-class employment in the East Asia sub-region, growing from less than $5 \%$ in 1991 to more than $60 \%$ of total employment in 2012. The Southeast Asia and the Pacific sub-region also experienced rapid growth in middle-class employment-an increase from 12 to $33 \%$ of the total workforce over the same period. In contrast, the middle class in South Asia still comprises only a very small segment of the sub-region's workforce-less than $9 \%$ in 2012, though this is a notable increase from $2 \%$ in 1991. As of 2012, over $61 \%$ of South Asia's workforce remains poor and a further $30 \%$ is near poor. 
(a)

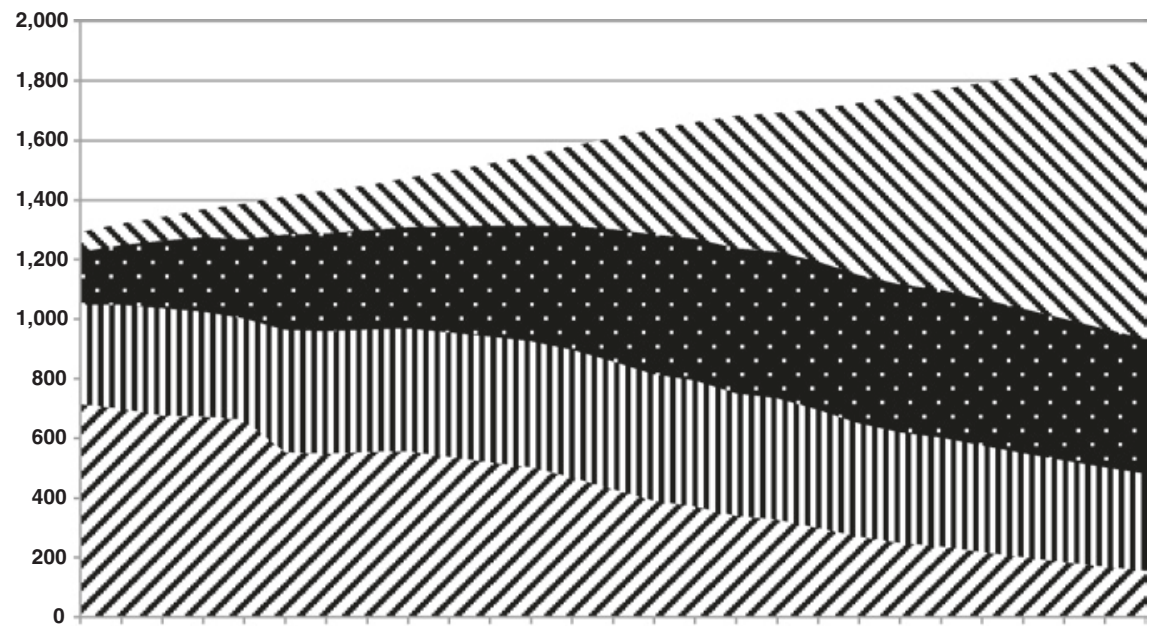

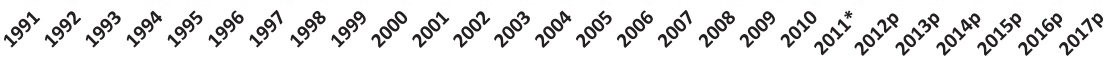

" Below US\$1.25 || US\$1.25-US\$2 $\approx$ US\$2-US\$4 $\leqslant$ US\$4 and above

(b)

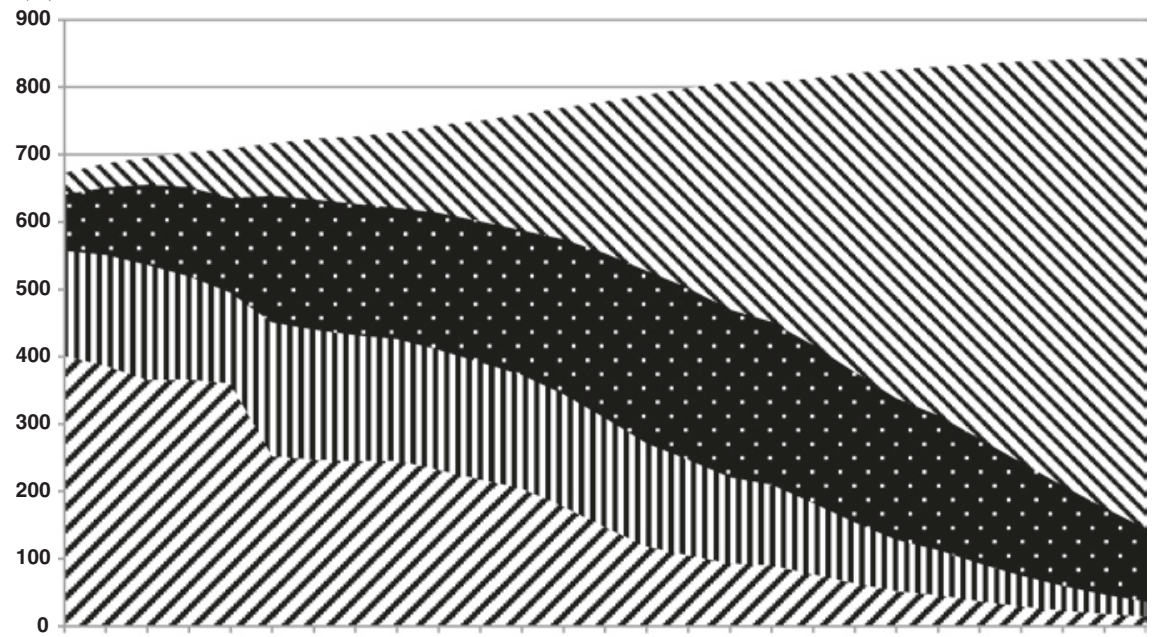

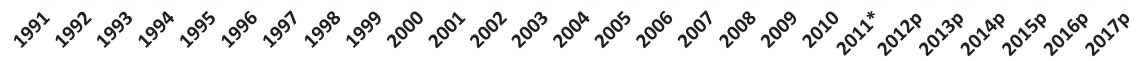

" Below US\$1.25 IIUS\$1.25-US\$2 $\approx$ US\$2-US\$4 :US\$4 and above

Fig. 14.1 Employment by economic class, 1991-2017, Asia and the Pacific and Asia-Pacific sub-regions (millions). a Asia and the Pacific. b East Asia. c Southeast Asia and the Pacific. d South Asia. Note "p" indicates projections; 2011 are preliminary estimates. Source Kapsos and Bourmpoula (2013) 
14 Economic Class and Labour Market Segregation ...


Fig. 14.1 (continued) 


\subsubsection{Projections, 2012-2017}

In the next several years, projections indicate continued rapid growth in Asia's middle class, which could grow to one-half of the total workforce in the region by 2017 . This is based on a projected acceleration in middle-class employment growth in East Asia (which is expected to see 180 million additional middle-class workers between 2012 and 2017). The overall regional projection for Asia and the Pacific is, therefore, heavily dependent upon the growth and employment performance in the People's Republic of China. The shares of the poor and near-poor workers are expected to decline in the region as a whole. In Southeast Asia and the Pacific, the share of workers in the extreme and moderate working poverty classes is expected to continue to decline substantially (less than $23 \%$ of the workers are projected to be poor in 2017 , a decline of 10 percentage points as compared with 2012), while the share of the near-poor workers is projected to change little, comprising around one-third of the sub-region's workforce in 2017.

The vast majority of workers in South Asia are projected to remain either poor or near poor in 2017, with around $87 \%$ of workers in the sub-region projected to be in the three lower economic classes. Lagging far behind the East Asia and Southeast Asia and the Pacific sub-regions, South Asia is likely to be home to more than threequarters of Asia's working poor in 2017, but for only $10 \%$ of the region's middleclass workers. Nevertheless, middle-class employment growth is accelerating in South Asia: middle-class employment is projected to equal $60 \%$ of all employment growth between 2012 and 2017 versus $33.5 \%$ of employment growth between 2001 and 2011. However, given the projected increase in the number of moderately poor and near-poor workers, poverty and vulnerability will remain widespread in South Asia.

\subsection{Distinguishing Class-Based Characteristics of the Labour Market}

Having presented an overview of the regional trends and medium-term outlook for reducing working poverty and fostering middle-class jobs, this section narrows in on four developing Asian countries, namely Cambodia, India, Indonesia and Viet Nam. It analyses the links between economic class, gender and different labour market variables related to economic participation and employment. It highlights the features that distinguish the poor from the middle class in terms of education, access to better quality jobs, working conditions and opportunities for young people.

\subsubsection{Economic Participation}

Figure 14.2 shows the distribution of the working age population (aged 15 and above) by labour force status for the different economic classes. In all four 


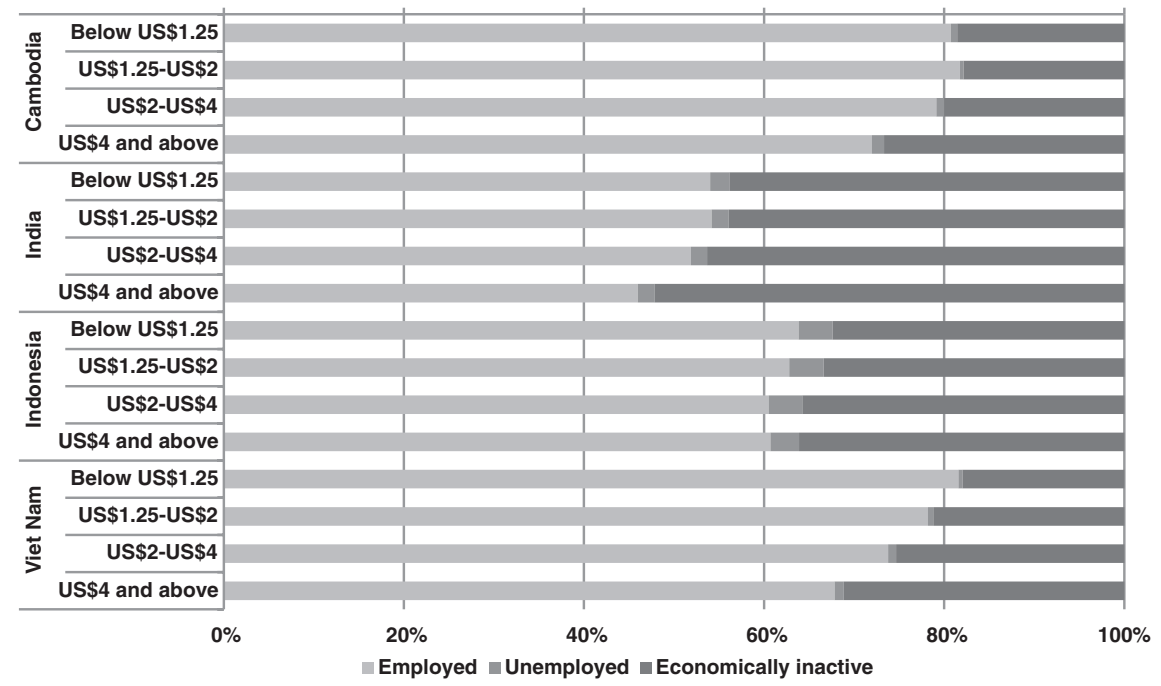

Fig. 14.2 Distribution of employed, unemployed and economically inactive in total population aged $15+$ by economic class, various years (\%). Source Authors' calculations from official national household surveys

countries, a majority of the poor and near poor were active in the labour market, with participation rates among these two economic classes around $55 \%$ in India, $66 \%$ in Indonesia, $78 \%$ in Viet Nam and $81 \%$ in Cambodia. Moreover, activity rates were consistently higher for the poor as compared to the middle class. This corroborates the widely accepted notion that in developing Asia, the poor are more likely to seek economic opportunities in the labour market given limited household income and material assets and gaps in formal social assistance mechanisms.

In India and Indonesia, the overall lower economic activity rates regardless of economic class can be attributed to the notable deficits in female participation in the labour force (see Fig. 14.3). The male-female gap in labour force participation was around 50 percentage points in India and 36 percentage points in Indonesia. Notably, in India, the gender gap in participation was around 53 percentage points for the poor, but was more than 10 percentage points lower (about 42 percentage points) for the middle class. A similar albeit less pronounced difference in gender gaps across economic classes was evident in Indonesia and Cambodia. This trend could be attributed to better sharing of household duties between men and women in middle-class families or the ability of more affluent families to hire domestic help which would allow more middle-class women the option to pursue career opportunities. Importantly, it points to the potential that a growing middle class can have in promoting women's economic participation and gender equality in the labour market. 


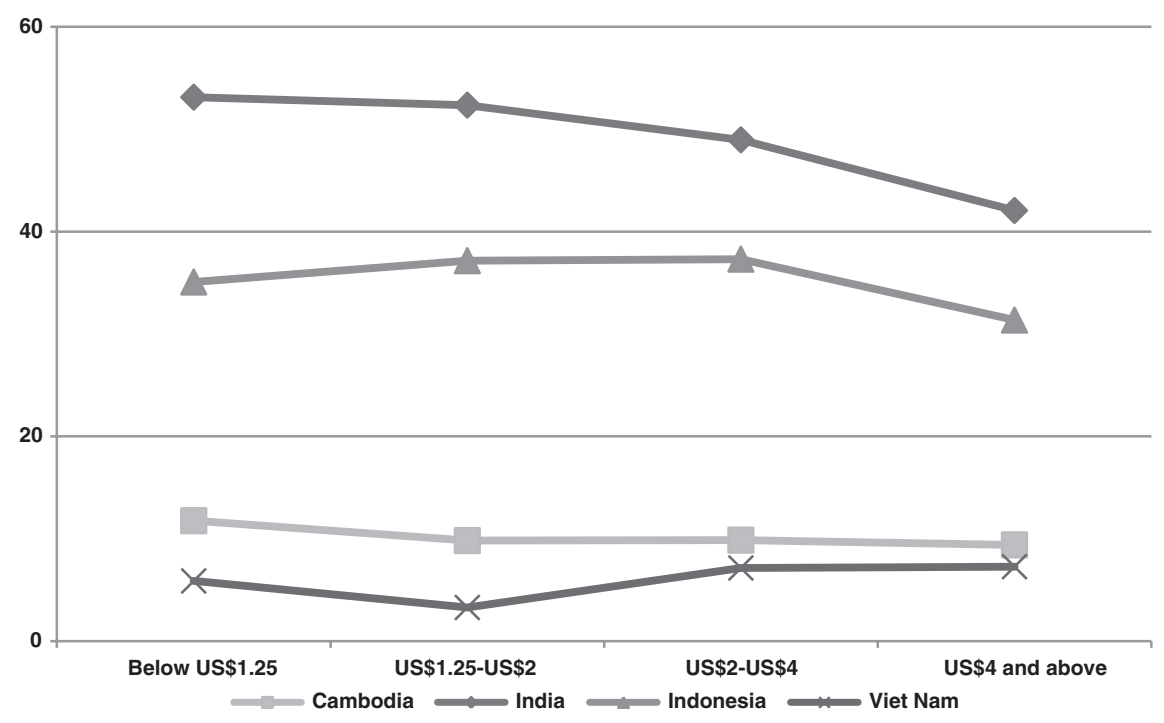

Fig. 14.3 Male-female gap in labour force participation rates aged $15+$ by economic class, various years (percentage points). Source Authors' calculations from official national household surveys

\subsubsection{Education Gaps and Middle-Class Opportunities}

The conceptual link between education and poverty reduction is well established, but how extensive is the class-based education gap and what distinct patterns emerge when comparing the poor, near-poor and middle-class workforces in our sample? First, as would be expected, educational attainment is consistently higher as household economic class increases (see Fig. 14.4). A majority of the economically active poor as well as the near poor had only a primary education or less. Moreover, tertiary education was almost non-existent among the extremely poor in all four countries and was still rare among the near poor.

Comparatively, education deficits among the economically active poor and near poor were most pronounced in Cambodia where the majority still lacked even primary education. However, among the middle class, around half of the economically active had a primary education. With regard to higher education, only a small minority of the labour force had attained a secondary or tertiary diploma. Even among the middle class, the proportion was only $14 \%$.

Viet Nam provides a stark contrast to Cambodia. Around $1 \%$ or less of the economically active across all economic classes had less than a primary education. However, while primary education completion rates were high, secondary and tertiary education remained elusive among the poor and near poor. By contrast, one salient characteristic of the economically active middle class in Viet Nam was their 


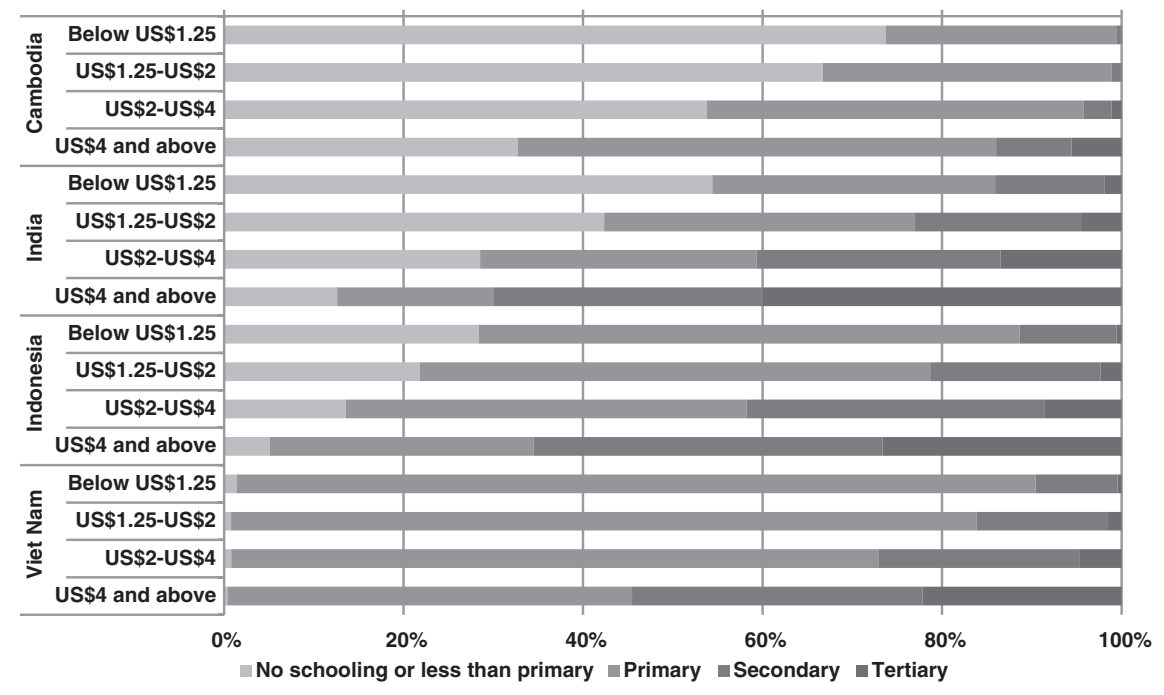

Fig. 14.4 Distribution of labour force aged 15+ by education and economic class, various years (\%). Source Authors' calculations from official national household surveys

higher education attainment: more than half had completed secondary education and a further one-fifth held a tertiary degree. Noteworthy also was the near gender parity in education achievement of the Vietnamese labour force regardless of poor or middle-class status.

India stands out for the sharp disparity in educational attainment across the different economic classes, and the linkages between poverty and education attainment are most evident here. Around 86 and $77 \%$ of the extremely and moderately poor, respectively, had only primary education or less. This percentage was considerably lower for the near poor $(59 \%)$ and the middle class $(30 \%)$. Interestingly, there was a sizeable male-female gap in primary education achievement (15 percentage points higher for men than women) among the extremely poor, but the disparity diminished gradually before reaching near parity among the middle class. Looking at tertiary education achievement alone, the share was around $40 \%$ for the middle class, but less than $2 \%$ among the extremely poor.

Indonesia shows similar although less pronounced education patterns as India. Nine-tenths of the extremely poor had only a primary education or less, and the share was four-fifths among the moderately poor and three-fifths for the near poor. By contrast, a majority (around two-thirds) of the middle-class workforce had completed at least secondary school, with a further one-quarter holding a tertiary degree. Conversely, tertiary education was almost absent among the poor; less than $1 \%$ of the extremely poor and around $2 \%$ of the moderately poor labour force had a tertiary degree. 
In sum, the main findings with regard to education of the labour force across the different economic classes include the following:

- Educational attainment of the labour force was highly related to economic class, with higher school achievement consistently associated with more affluent economic status.

- With the exception of Cambodia where education was generally lower across all economic classes, a prominent majority of the near-poor labour force in the other three countries had at least basic education at the primary level. For the economically active middle class, a majority in India, Indonesia and Viet Nam had at least a secondary degree.

- Tertiary education was nearly non-existent among the poor and accessible predominantly to the middle class in the four-country sample.

- In two of the four countries (Cambodia and India), gender-related deficits in education achievement were prevalent particularly among the poor and near poor, with considerable disadvantages for women. However, these male-female education gaps were notably lower among the middle class.

\subsubsection{Working Poverty and Middle-Class Jobs}

Having looked at economic participation and education, this section focuses on the distinct employment characteristics that differentiate the poor, near-poor and middle-class workers in the four-country sample.

Table 14.1 shows the distribution of the employed population by economic class and sex, revealing a number of prominent features. First, working poverty was pervasive in all four countries. Based on the US\$1.25 per day poverty line, the working poverty rate was $28 \%$ overall and ranged from $20 \%$ in Viet Nam to $37 \%$ in Cambodia. The share of workers living in moderate poverty (less than US\$2 per day) was also alarming - around half of all workers in Viet Nam and two-thirds of all workers in Cambodia, India and Indonesia. Regarding gender differences, working poverty rates (including both the extremely and moderately poor) for women were only marginally higher than for men in all four countries.

Second, comparatively small portions of the employed population were classified as middle class or above in the four countries. This ranged from approximately $7 \%$ in India and Indonesia to $16 \%$ in Viet Nam. In all four countries, male workers were more likely than women workers to be middle class, with the exception of Indonesia. Reflecting the sizeable male-female gap in labour force participation in India and Indonesia, as discussed in Sect. 14.4.1, the total population of middle-class working men outnumbered middle-class working women by 3 times in India and by nearly 2 times in Indonesia.

Moreover, an important distinction is that nearly three in ten workers in the four countries remained near poor and had not yet reached middle-class status. These workers were particularly vulnerable to falling back into poverty. In addition to the 
Table 14.1 Employed population aged $15+$ by sex and economic class, various years

\begin{tabular}{l|l|l|l|l|l}
\hline & \multicolumn{2}{|l}{} & Distribution of employed population $(\%)$ & Total \\
\cline { 2 - 5 } & Below US\$1.25 & US\$1.25-US\$2 & US\$2-US\$4 & US\$4 and above & $\begin{array}{l}\text { employed } \\
\text { population } \\
\text { (000s) }\end{array}$ \\
\hline Cambodia & 36.5 & & 24.9 & 9.6 & 6,622 \\
\hline Male & 36.7 & 29.0 & 24.7 & 9.9 & 3,339 \\
\hline Female & 36.3 & 28.6 & 25.1 & 9.2 & 3,283 \\
\hline India & 29.3 & 29.4 & 27.2 & 6.5 & 374,286 \\
\hline Male & 29.0 & 37.0 & 27.3 & 6.6 & 278,050 \\
\hline Female & 30.2 & 37.0 & 26.8 & 6.0 & 96,236 \\
\hline Indonesia & 27.4 & 37.0 & 27.7 & 7.1 & 91,057 \\
\hline Male & 26.7 & 37.8 & 28.1 & 6.9 & 57,904 \\
\hline Female & 28.5 & 38.3 & 26.9 & 7.6 & 33,153 \\
\hline Viet Nam & 20.2 & 37.0 & 36.3 & 16.0 & 47,161 \\
\hline Male & 19.6 & 27.5 & 36.9 & 16.5 & 23,701 \\
\hline Female & 20.8 & 27.1 & 35.7 & 15.6 & 23,459 \\
\hline Total & 28.3 & 27.9 & 28.1 & 7.5 & 519,125 \\
\hline Male & 28.1 & 36.2 & 28.0 & 7.3 & 362,994 \\
\hline Female & 28.6 & 36.5 & 28.1 & 7.9 & 156,131 \\
\hline
\end{tabular}

Note Total figures represent the distribution of the aggregated employed population across the four-country sample

Source Authors' calculations from official national household surveys

working poor, this group should not be overlooked by policy-makers, given the potential of an unexpected economic, social or environmental shock that could detrimentally impact household income and consumption levels and push families into poverty. ${ }^{4}$ These findings have profound implications, in particular, for social protection measures, including basic health and income support systems, in developing Asia.

\subsubsection{The Challenge of Vulnerable and Casual Employment}

Analysis of workers by employment status is instrumental in providing insights into the conditions and security of employment and the extent that workers are engaged in vulnerable jobs. Applying the widely accepted international definition, the vulnerable employment rate in our analysis is defined as the proportion of own account and contributing family workers in total employment. In contrast to wage or salaried

\footnotetext{
${ }^{4}$ Research indicates that both the 1997-98 Asian financial crisis and the 2004 Indian Ocean Tsunami, for example, exacerbated the poverty situation in a number of developing countries in the region. See Jonas and Marsden (2010) and Hagiwara and Sugiyarto (2005).
} 
employees, workers in these categories are employed in relatively precarious circumstances, are less likely to have formal work arrangements, access to benefits or social protection systems and are more at risk during an economic downturn. ${ }^{5}$

Across the four-country sample, 267.7 million workers (more than one in two) were in vulnerable employment as an own account or contributing family worker, reflecting the poor quality of jobs overall. Nearly half of all workers in India were classified as holding a vulnerable job, while the comparable ratios were nearly three-fifths in both Indonesia and Viet Nam and three-fourths in Cambodia. The relatively lower vulnerable employment rate in India, however, should not overshadow another group in that country that faced significant labour market deficits-casual wage earners employed on a temporary or short-term basis (as discussed below).

When assessing differences among the economic classes, however, a paramount characteristic emerges: vulnerable employment rates were significantly higher among the poor and near poor in all four countries and notably less common among the middle class. In Indonesia, for example, the class-based difference in vulnerable employment rates was the most glaring, at 34 percentage points higher for the extremely poor than for middle-class workers. From a different perspective, the poor and near poor accounted for $96 \%$ of all own account and contributing family workers in Indonesia, $95 \%$ in India, $92 \%$ in Cambodia and $87 \%$ in Viet Nam. Clearly, having middle-class status is categorically linked to a worker's ability to access non-vulnerable forms of employment with greater stability and security.

Another important and common distinction in all four countries was the higher rate of vulnerable jobs among women than men (see Fig. 14.5). The gender gap was particularly pronounced in Viet Nam (18 percentage points) and Indonesia (10 percentage points). Moreover, in Viet Nam, the male-female difference in the vulnerable employment rate was lowest among the middle class (12 percentage points), but gradually increased as economic class status declined, reaching 23 percentage points among the extremely poor. By contrast, the opposite pattern emerged in Cambodia and India - the gender discrepancy in the vulnerable employment rate was lowest among poor workers, but highest among the middle class. While the correlation between gender disparity in vulnerable jobs and economic class is not uniform, what is clear is that women consistently faced greater difficulty than men within the same economic class in accessing better quality, non-vulnerable jobs.

While working on one's own account or contributing to a family-based establishment is often indicative of poor job quality, regular salaried employment is commonly assumed to provide better working conditions and security, and higher earnings and greater benefits. In all four countries, the percentage of the workforce engaged in regular wage employment was considerably low, at around one-fifth in India and Cambodia and approximately two-fifths in Indonesia and Viet Nam. ${ }^{6}$

\footnotetext{
${ }^{5}$ For further discussion on the vulnerable employment indicator, see ILO (2013a).

${ }^{6}$ It should be noted that the Cambodia and Viet Nam survey data do not have a separate distinction for regular versus casual wage earners, and therefore, indicators on wage employment for both countries are not strictly comparable with India and Indonesia.
} 


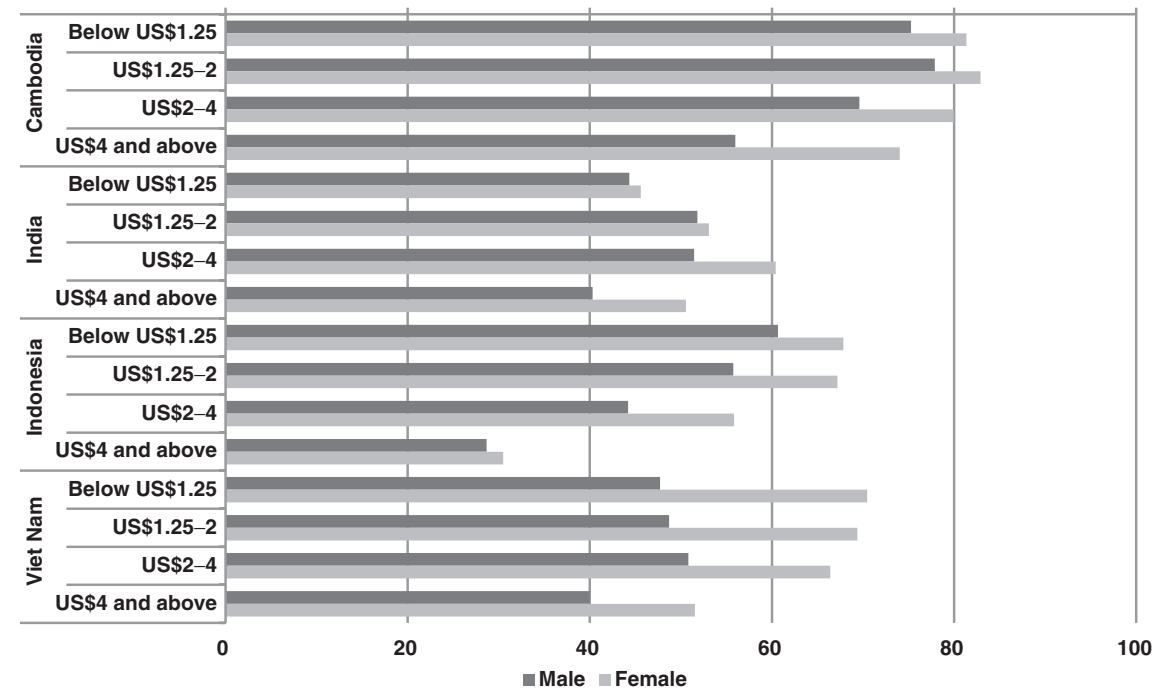

Fig. 14.5 Share of vulnerable employment (own account and contributing family workers) in total employed population aged $15+$ by sex and economic class, various years (\%). Note Viet Nam survey data do not include a separate classification for contributing family workers. Source Authors' calculations from official national household surveys

Looking at wage employment rates and economic class in each country, a prominent pattern is evident: regular wage employment was atypical among the poor, more common among the near poor and a defining feature of the middle class (see Fig. 14.6). In Cambodia and Viet Nam, the share of regular wage employment among the middle class was 14 percentage points higher than for the extremely poor, while the comparable difference was nearly 40 percentage points in both India and Indonesia. These findings about better access to wage employment among the middle class are consistent with Banerjee and Duflo (2008).

Working conditions for wage employees can also be insecure and precarious when these workers are employed casually on a temporary, seasonal or short-term basis. $^{7}$ In both India and Indonesia, the share of casual wage workers notably declined as economic class status increased. More than $46 \%$ of all extremely poor Indian workers were engaged in casual wage employment, but the share was

\footnotetext{
7 In India, a casual worker is defined as "a person casually engaged in other's farm or non-farm enterprises (both household and non-household) and getting in return wage according to the terms of the daily or periodic work contract". See India Ministry of Statistics and Programme Implementation. Available at: http://164.100.34.58/index.php/catalog/18 (accessed 19 June 2013). In Indonesia, casual day workers are defined as "workers who receive a daily wage. These wages may be given weekly or monthly, depending on the work output. Included are casual workers who are paid according to the volume/output of work which they perform or are contracted for". See Badan Pusat Statistik (Statistics Indonesia). Available at http://www.bps.go.id/eng/menutab.p $\mathrm{hp} ? \mathrm{tab}=4 \&$ tabel $=1 \& \mathrm{~kat}=1 \& \mathrm{id} \_$subyek $=06 \& \mathrm{ist}=1 \& \mathrm{var}=\mathrm{C}($ accessed 19 June 2013).
} 


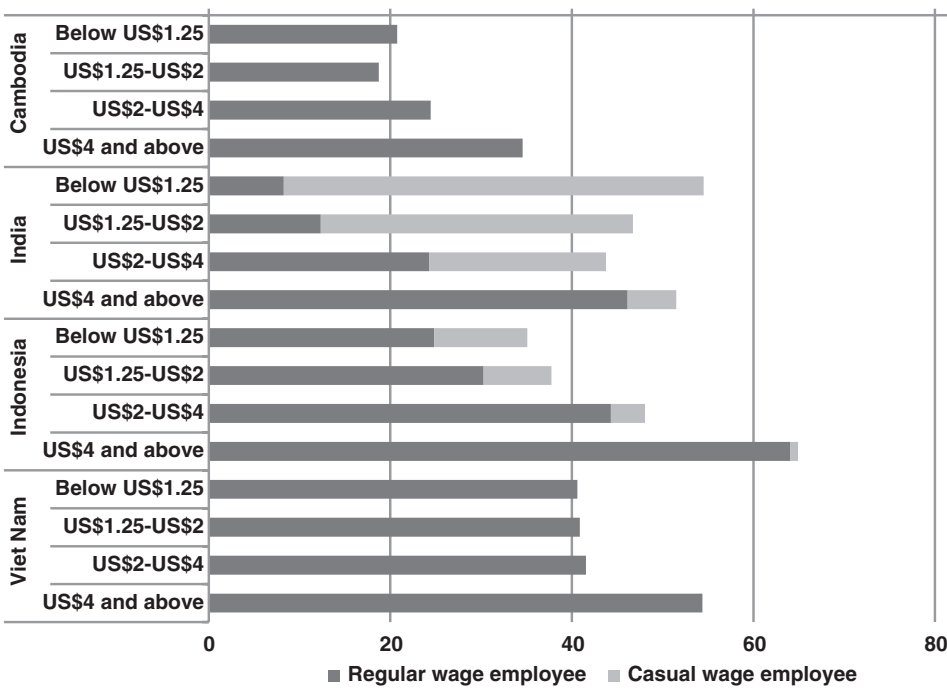

Fig. 14.6 Share of regular and casual wage employees in total employed population aged $15+$ by economic class, various years (\%). Note Cambodia and Viet Nam survey data do not include a separate classification for casual wage workers. Source Authors' calculations from official national household surveys

around $20 \%$ for the moderately poor and merely $5 \%$ for the middle class. Likewise, casual employment rates were less than $1 \%$ for the middle-class Indonesian workers, but more than $10 \%$ for the extremely poor. In sum, the probability of working in a casual, salaried job significantly increases with less affluent class status in both countries, and this pattern is consistent when looking separately at male and female casual wage earners.

\subsubsection{Agricultural Poverty Trap and Opportunities in Manufacturing}

This section examines whether workers from a particular economic class are more likely to be employed in a certain economic sector. Figure 14.7 reveals a stark and consistent pattern across all four countries-the likelihood of working in agriculture was drastically higher with lower economic status. Conversely, as economic class status increased, the chances of being employed in the services sector rose significantly. These findings corroborate the notion that in order to expand the middle class, rural workers must be supported by raising agricultural productivity and incomes while also facilitating the structural transition of workers out of agriculture and into better jobs in higher value-added services. ${ }^{8}$

\footnotetext{
${ }^{8}$ For further discussion on the importance of the services sector on inclusive growth, development and employment creation, see Asian Development Bank (2012).
} 


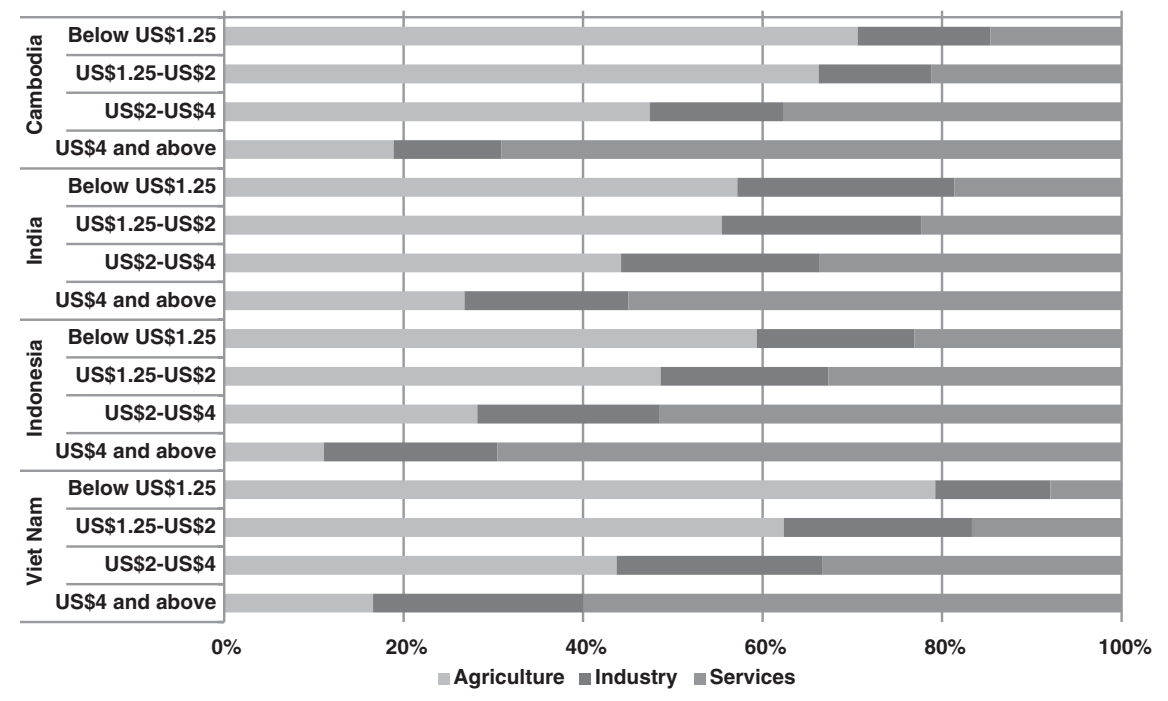

Fig. 14.7 Distribution of employed population aged $15+$ by economic sector and economic class, various years (\%). Source Authors' calculations from official national household surveys

Given the evident differences in employment in agriculture and services across economic class, are there defining traits that characterize the linkage between industrial employment and economic class? Surprisingly, with the exception of Viet Nam, the share of employment in the industrial sector was generally consistent across all economic classes in each country, at around $14 \%$ in Cambodia, $19 \%$ in Indonesia and $23 \%$ in India. Overall, holding an industrial job, unlike employment in agriculture and services, appears less likely to be tied to a worker's economic class in the four-country sample.

Manufacturing is one vital sub-sector worthy of further examination considering its role in developing Asia in driving export-led growth, increasing living standards and generating salaried jobs for women. ${ }^{9}$ When assessing the opportunities created by manufacturing jobs for different economic classes, different patterns emerge in the four countries (see Fig. 14.8). In Cambodia, the extremely poor were the most common economic class working in manufacturing (around $38 \%$ ), which could reflect the low pay and low skill nature of the country's garment manufacturing industry. In India and Indonesia, manufacturing consisted of mostly moderately poor workers (approximately $36 \%$ ) but also workers from near-poor families (about $30 \%$ ). In Viet Nam, extremely poor workers were mostly absent in manufacturing, accounting for less than $10 \%$, while the near poor were the most prominent class at almost $43 \%$. In sum, the manufacturing sector appears to have created jobs for different classes of workers in the four countries,

${ }^{9}$ For example, see Felipe and Estrada (2007) and ADB and ILO (2011). 


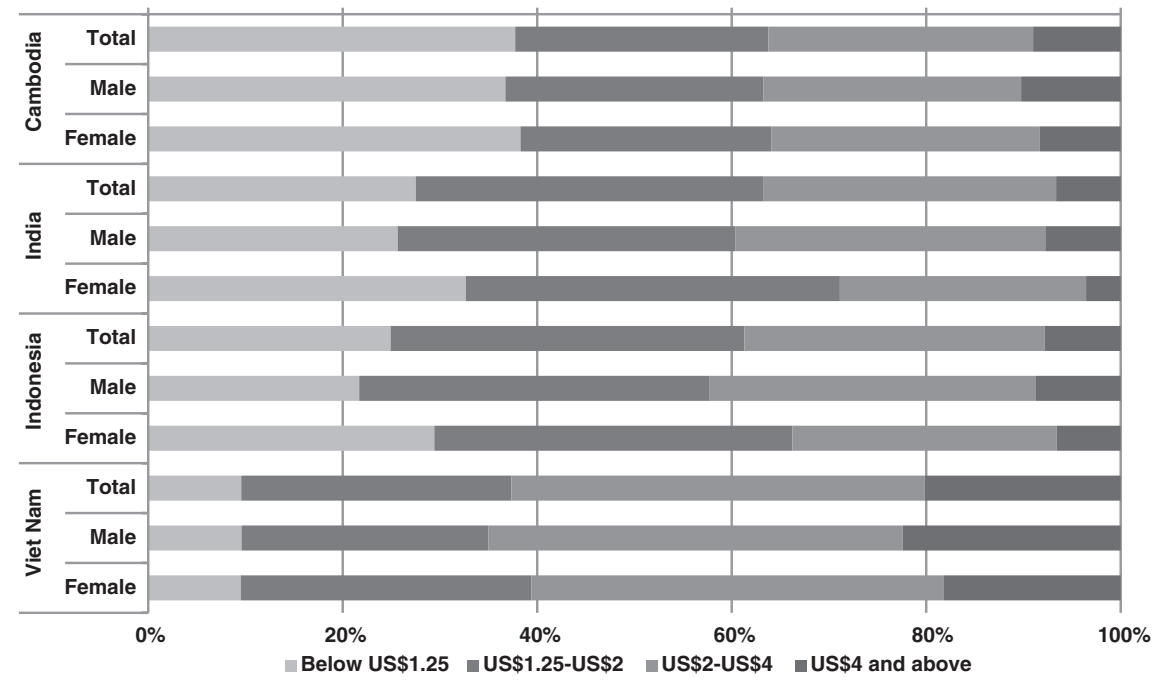

Fig. 14.8 Distribution of employed population in manufacturing aged $15+$ by sex and economic class, various years (\%). Source Authors' calculations from official national household surveys

on one hand benefiting more of the extremely poor in Cambodia, but more of the moderately poor in India and Indonesia and predominantly the near poor in Viet Nam.

\subsubsection{Class and Occupational Segregation}

Another critical dimension of job quality relates to the type of occupation and requisite skill level. High-skilled occupations often entail a significant level of creative, decision-making, technical and communication competencies and generally earn higher wages and offer better working conditions. In our analysis, we adopt the international standard approach for defining high-skilled, non-manual occupations, namely legislators, senior officials, managers, professionals, technicians and associate professionals. In terms of formal education and training levels, these high-skilled occupations correspond to the first and second stage of tertiary education, although the necessary skills can also be developed through informal training and experience. ${ }^{10}$

Looking at economic class and segregation in occupations that characterize these types of managerial and high-skilled professions further highlights substantial disparities in access to better jobs (see Fig. 14.9). In the four-country sample, around one in three middle-class workers had a high-skilled occupation, but the proportion was less than one in twenty among the extremely poor. Notably,

${ }^{10}$ For further discussion, see ILO (2012a, b, 2013b). 


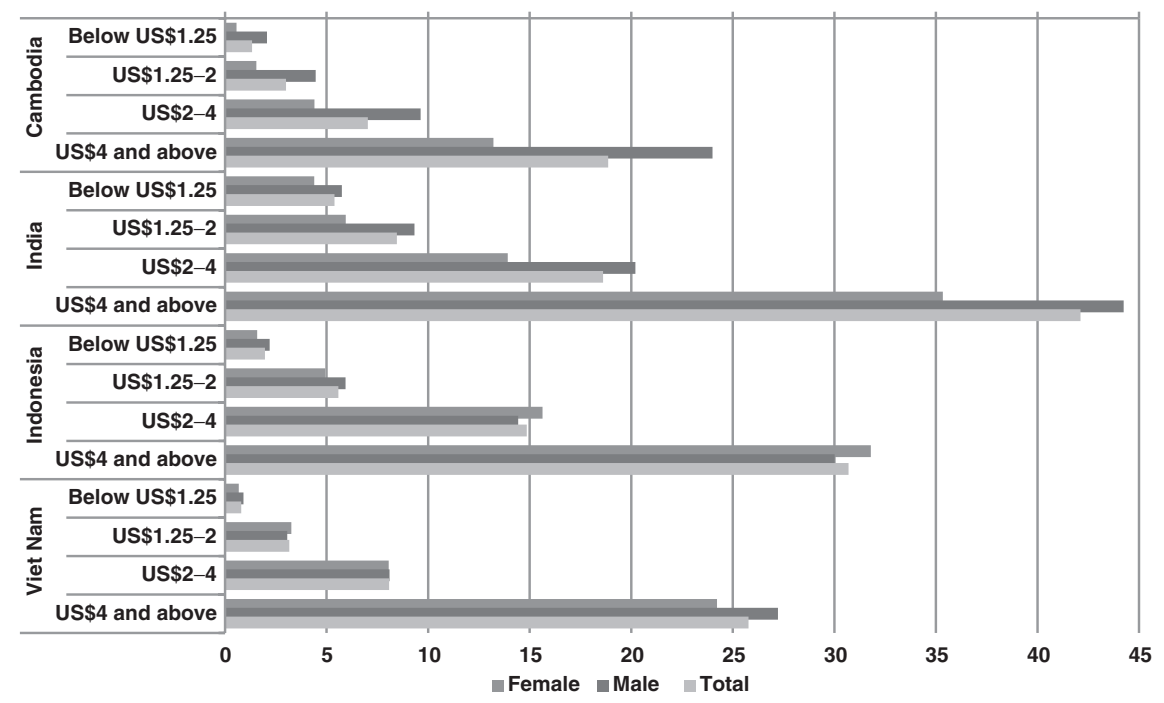

Fig. 14.9 Share of high-skilled occupations in total employed population aged $15+$ by sex and economic class, various years (\%). Note High-skill occupations are defined as International Standard Classification of Occupations (ISCO-88) Major Group 1 (legislators, senior officials and managers), Major Group 2 (professionals) and Major Group 3 (technicians and associate professionals). Source Authors' calculations from official national household surveys

middle-class workers were 32 times more likely to have a high-skilled occupation than extremely poor workers in Viet Nam. The comparable ratios were 16 in Indonesia, 14 in Cambodia and 8 in India. In the light of the previous discussion on inequality in educational attainment, too many poor workers, especially women, in developing Asia clearly lack the crucial education, training and professional experience to compete for these high-skilled jobs.

\subsubsection{Sufficiency of Working Hours to Escape Poverty}

Analysis of working time is useful for gaining further insights into the working conditions of developing Asia's poor, vulnerable and middle-class workers. Excessive hours of work, for example, could signify potential negative effects on workers' health and safety as well as work-life balance (ILO 2012a). However, given the alarming shares of workers self-employed on their own account or in casual salaried jobs, as discussed above, these workers in particular may seek more hours of work in order to increase total earnings and aggregate household income in spite of any related adverse consequences.

In Indonesia, workers averaged $39 \mathrm{~h}$ per week, with men employed for $41 \mathrm{~h}$ and women for $35 \mathrm{~h}$. Workers in Cambodia worked, on an average, slightly more than $41 \mathrm{~h}$ per week, with higher working time for men (43 h) compared to women (40 h). Meanwhile, working time in Viet Nam was even higher overall: $46 \mathrm{~h}$ on 


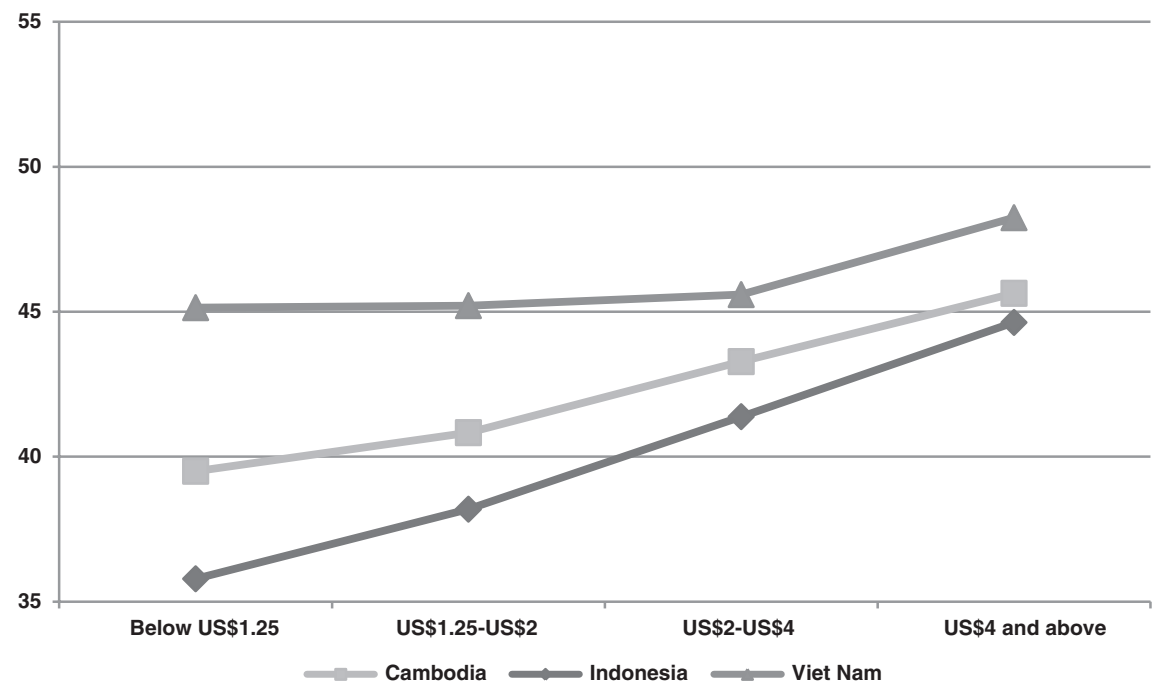

Fig. 14.10 Average weekly hours of work of employed population aged $15+$ by economic class, various years. Source Authors' calculations from official national household surveys

average (47 $\mathrm{h}$ for men and $44 \mathrm{~h}$ for women). ${ }^{11}$ The male-female difference in working time in these three countries most likely reflects the comparably greater engagement of women in household duties that are not reflected statistically in the system of national accounts and, therefore, not counted as hours of work.

When looking at the average working time across economic class, a distinctive pattern emerges (see Fig. 14.10). In all three countries, the average hours of work increased with economic class status, with the extremely poor averaging the fewest hours (as low as $36 \mathrm{~h}$ per week in Indonesia) and the middle-class working the longest hours (as many as $48 \mathrm{~h}$ in Viet Nam). This trend was also consistent when looking separately at men and women workers.

Because our analysis examines working time in all jobs held during the reference period, these findings could underscore the reality that in developing Asia, many workers are engaged in multiple jobs and the amount of earnings (and thus total household income and expenditure levels) will depend in part on one's ability to access additional working hours in secondary occupations. For the middle-class worker, opportunities for working extra hours to supplement income seem greater than for the working poor. Thus, while there is a common perception that the poor work long hours with little pay, the evidence points to a slightly different realitythat the poor may be earning too little and are stuck working hours insufficient to lift themselves and their families out of poverty.

11 Information on working time in India is not available from the survey data and is, therefore, not discussed in this section. 


\subsection{Conclusion}

Using an absolute definition of poverty and the middle class, this paper provides some important insights into the profiles of the poor, near-poor and middle-class workforce in developing Asia and the Pacific, with a special focus on Cambodia, India, Indonesia and Viet Nam. By applying a class-based framework for assessing the labour market, the paper sheds light on decent work challenges that must be addressed in order to eradicate working poverty and foster growth of the middle class in the region.

Overall, the paper presents a number of key findings. First, in recent decades, the region has achieved remarkable progress in reducing working poverty and fostering a sizeable middle class that is projected to account for half of the workforce (932 million) by 2017. However, working poverty remains pervasive. In Asia and the Pacific, 603 million workers still lived under the US\$2 poverty line in 2012. Moreover, another 497 million workers lived just above the poverty line (US\$2US\$4) and were vulnerable to falling back into poverty due to an unforeseen emergency or crisis.

Second, education levels of the workforce are positively linked to household affluence, with secondary and tertiary education still elusive for too many living under or just above the poverty line. In order to nurture and expand the middle class, strengthening access to and improving the relevance of higher education and vocational training for the poor and near poor is imperative. This would help them develop the higher level skills needed to compete for more productive jobs that provide better wages and earnings.

Third, the quality and security of work-as measured by the prevalence of vulnerable and casual jobs, employment in low-productivity agriculture and sufficient working hours - are measurably associated with economic class. In developing Asia, the poor and near poor face stark disadvantages in terms of access to quality jobs. To this end, increasing infrastructure investment and facilitating sectoral shifts from agriculture to higher value-added industry and services are critical. Moreover, better labour market governance could help improve working conditions and boost wages.

Fourth, gender disparities in terms of job quality are pervasive with women facing greater challenges than men regardless of economic class. However, with higher household affluence, gender gaps in education and economic participation tend to be lower. This positive finding highlights the potential impact of middleclass opportunities and values on reducing gender discrimination in society and the labour market.

While this paper provides quantitative evidence for targeted interventions that can accelerate poverty reduction and the growth of the middle class in developing Asia and the Pacific, it represents only a starting point. In this regard, the information base would benefit greatly from a similar analysis of national household data for the same four countries in our sample, but in different survey years, as well as research into other countries in developing Asia and the Pacific. The former 
would also provide the requisite data and analysis to track trends and progress over time. In addition, econometric analysis of the relationship between household characteristics, class status and labour market outcomes would be invaluable for designing effective labour market and social policies that can contribute to eradicating working poverty and nurturing middle-class jobs.

Acknowledgments This paper benefited from very helpful comments and contributions provided by ILO colleagues including Matthieu Cognac, Kee Beom Kim, Makiko Matsumoto, Theodoor Sparreboom, Sher Verick, Christian Viegelahn, Christina Wieser and David Williams. Special mention should be given to Andrea Silberman who supported the statistical tabulations of household survey data. Any errors are the sole responsibility of the authors.

Open Access This chapter is distributed under the terms of the Creative Commons Attribution Noncommercial License, which permits any noncommercial use, distribution, and reproduction in any medium, provided the original author(s) and source are credited.

\section{References}

Asian Development Bank (2012) Asian development outlook 2012 update: services and Asia's future growth. ADB, Manila

Asian Development Bank and International Labour Office (2011) Women and labour markets in Asia: rebalancing for gender equality. ILO, Bangkok

Banerjee AV, Duflo E (2008) What is middle class about the middle classes around the world? J Econ Perspect 22(2):3-28

Chen S, Ravallion M (2008) The developing world is poorer than we thought, but no less successful in the fight against poverty. Policy research working paper no. 4703. The World Bank, Washington, D.C.

Chun N (2010) Middle class size in the past, present and future: a description of trends in Asia. ADB economics working paper series no. 217. ADB, Manila

Felipe J, Estrada G (2007) Benchmarking developing Asia's manufacturing sector. ERD working paper series no. 101. ADB, Manila

Ferreira F et al (2013) Economic mobility and the rise of the Latin American middle class. The World Bank, Washington, D.C.

Hagiwara AT, Sugiyarto G (2005) Poverty impact of the tsunami: an initial assessment and scenario analysis. Paper presented during the 4th PEP research network general meeting, Colombo, 13-17 June 2005

ILO (2012a) Decent work indicators: concepts and definitions: ILO manual, 1st edn. ILO, Geneva

ILO (2012b) International standard classification of occupations (ISCO-08). ILO, Geneva

ILO (2013a) Global employment trends 2013: recovering from a second jobs dip. ILO, Geneva

ILO (2013b) Global employment trends for youth 2013: a generation at risk. ILO, Geneva

Jonas S, Marsden H (2010) Assessing the impacts of and responses to the 1997-98 Asian financial crisis through a child rights lens: Including children in policy responses to previous economic crises. UNICEF, New York

Kapsos S (2004) Estimating growth requirements for reducing working poverty: can the world halve working poverty by 2015 ? Employment strategy paper no. 14. ILO, Geneva

Kapsos S, Bourmpoula E (2013) Employment and economic class in the developing world. ILO research paper no. 6. ILO, Geneva 
Kharas $H$ (2010) The emerging middle class in the developing countries. Organisation for Economic Co-operation and Development (OECD) Development Centre working paper no. 285. OECD, Paris

Loayza N, Rigolini J, Llorente G (2012) Do middle classes bring institutional reforms? Policy research working paper no. 6015. The World Bank, Washington, D.C.

Ravallion M (2009) The developing world's bulging (but vulnerable) 'middle class'. Policy research working paper no. 4816, The World Bank, Washington D.C. 